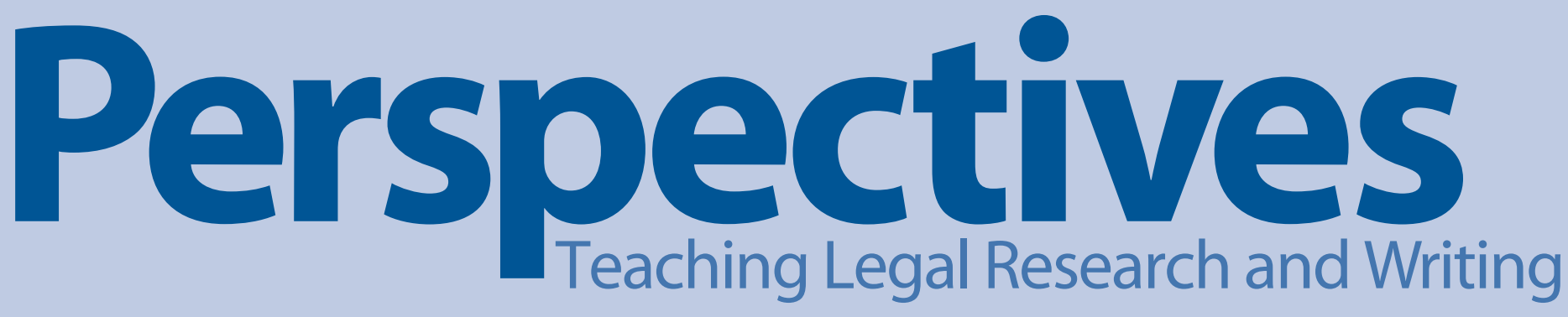

Vol. 16 | No. 2 | Winter 2008

\title{
Writing Engaging, Realistic, and Balanced Appellate Advocacy Problems
}

By James D. Dimitri

\begin{abstract}
Jim Dimitri is a Clinical Associate Professor of Law at Indiana University School of Law in Indianapolis, where he teaches legal analysis, research, and communication; appellate advocacy; transactional drafting; advanced persuasive writing; and advanced oral advocacy. He is also a faculty adviser for the school's moot court program.
\end{abstract}

It's the winter holiday break. You've just finished grading your final office memorandum from the fall semester and you feel relieved. It's time for some well-earned relaxation!

Unfortunately, you don't have much time to breathe easily because another important task awaits - the preparation of persuasive writing assignments for the spring semester. Chances are that one of these assignments is an appellate advocacy assignment, likely to be given to your students as the major assignment of the semester. Perhaps the assignment is even part of your school's moot court competition. The assignment will require your students to prepare an appellate brief and deliver an appellate oral argument.

Any professor who has been responsible for creating an appellate advocacy problem will agree that it can be very time-consuming and maybe even daunting. A topic for the problem needs to be selected, followed by thorough research to gather relevant authority. But even more importantly, the problem must hold pedagogical value for the students. Specifically, the problem should be engaging and challenging for the students, yet it must also be manageable for them so they don't become frustrated. Moreover, the problem should give the students a realistic portrayal of the appellate process so the students are not surprised when they enter law practice and run into aspects of the appellate process for which their appellate advocacy experience did not prepare them.
In nearly 10 years of teaching, I have written more than a dozen appellate problems for use in my school's legal writing program and in the school's moot court competition. I've seen the headaches that can result from the process of creating the problem. I've seen the awkward and confusing moments that my students went through when working on problems that didn't work well. And, I've seen the valuable educational moments that resulted when the problem I wrote was engaging, realistic, and balanced. Therefore, to provide guidance to other faculty who are faced with the task of writing an appellate problem, I will share the methods that I have found to be the most effective in writing a good problem. ${ }^{1}$

\section{Create an Engaging Problem}

During my second year of teaching, I gave an appellate advocacy assignment to my legal writing

\footnotetext{
${ }^{1}$ In this article, I don't mean to discourage legal writing teachers from borrowing appellate advocacy problems from resources such as the Legal Writing Institute's Idea Bank. These resources are certainly valuable, particularly to educators who are new to the legal writing field. The objective of this article is merely to provide guidance to professors who wish to try their own hand at drafting appellate advocacy problems.
}

Printed by West as a service to the Legal Community. 
93 Writing Engaging, Realistic, and Balanced Appellate Advocacy Problems

James D. Dimitri

100 Persuasion in a Familiar Activity: The Parallels Between Résumé Writing and Brief Writing

Patricia Grande Montana

106 Insights from Clinical Teaching: Learning About Teaching Legal Writing from Working on Real Cases

Helen A. Anderson

Brutal Choices in Curricular Design ...

109 A Schema Walks into a Bar ... How Humor Makes Us Better Teachers by Helping Our Students Learn

James B. Levy

112 In-Class Online Legal Research Exercises:

A Valuable Educational Tool

Tom Kimbrough

118 Teaching Research a New Way

Maurine J. Berens and Kathleen Dillon Narko

122 Developing Internal Consistency in Writing Assignments by Involving Students in Problem Drafting

Karin Mika

125 Getting Them While They're Young: Two Experiences Using Traditional Legal Practice Skills to Interest High School Students in Attending Law School

Angela M. Laughlin

Writing Tips ...

131 To Go Boldly Without the Bold (and Italics and Underlining and Caps)

Benjamin R. Opipari

139 Legal Research and Writing Resources:

Recent Publications

Barbara A. Bintliff

147 In Memoriam: Donald J. Dunn
Perspectives: Teaching Legal Research and Writing is published in the fall, winter, and spring of each year by West.

\section{Editor}

Mary A. Hotchkiss

University of Washington School of Law

and the Information School

Seattle, Washington

\section{Editorial Board}

Barbara A. Bintliff

University of Colorado

School of Law Library

Boulder, Colorado

Elizabeth Edinger

Catholic University of

America Law Library

Washington, D.C.

Penny A. Hazelton

University of Washington

School of Law Library

Seattle, Washington

Judith Meadows

State Law Library

of Montana

Helena, Montana

Kathryn S. Mercer

Case Western Reserve

University School of Law

Cleveland, Ohio

Helene S. Shapo

Northwestern University

School of Law

Chicago, Illinois

Craig T. Smith

Vanderbilt University

Law School

Nashville, Tennessee

Kay Todd

Paul Hastings Janofsky

\& Walker

Atlanta, Georgia

Opinions expressed in this publication are those of the authors and should not be attributed to the Editor, the Editorial Board, or West.

Readers are encouraged to submit brief articles on subjects relevant to the teaching of legal research and writing. Manuscripts, comments, and correspondence should be sent to:

Mary A. Hotchkiss, William H. Gates Hall, Box 353020, Seattle, WA, 98195-3020. Phone: 206-616-9333

Fax: 206-543-5671 E-mail: hotchma@u.washington.edu

To subscribe to Perspectives, use the card inside this issue or contact:

Ann Laughlin, West, Customer and Product Documentation, D5-S238, 610 Opperman Drive, Eagan, MN 55123. Phone: 651-687-5349

E-mail: ann.laughlin@thomson.com

west.thomson.com/newsletters/perspectives

Printed by West as a service to the Legal Community. 
students that I thought they would enjoy. The problem involved an appeal under the Visual Artists Rights Act of 1990 (VARA) ${ }^{2}$, which was a relatively new statute at the time that I assigned the problem. VARA creates a cause of action for artists whose "work[s] of visual art" have been intentionally distorted or mutilated by another. ${ }^{3}$ In the case, a group of radicals defaced a series of original lithographs. The artist who created the lithographs then sued the defacers under VARA. The artist lost in the lower court and appealed. The issue on appeal was whether the defaced lithographs were "work[s] of visual art" covered by VARA.

Sounds like it might be an interesting assignment, right? On the surface, it was. Unfortunately, however, the actual issue that I chose for the students to brief and argue ended up being dull. Whether the defaced lithographs were works of visual art under VARA hinged upon whether they were created by the artist as an independent contractor or an employee. ${ }^{4}$ To make this determination, the students had to use an unwieldy 13factor balancing test that included drab factors such as whether the person who commissioned the artist paid employee benefits to the artist. ${ }^{5}$ During oral arguments, my students displayed little enthusiasm for the case. In addition, I and my fellow judges were bored.

This war story leads me to emphasize that your first goal as an appellate advocacy problem writer should be to choose a problem topic that the students, as well as any outside judges who may score their briefs and oral arguments, will find interesting. There are two reasons for this goal. First, interesting problems provide a much more valuable learning experience than problems that focus on obscure, dull, or overly technical legal topics. In my experience, this is so because students

\footnotetext{
217 U.S.C.A. $\$ 106$ A.

317 U.S.C.A. $\$ 106 \mathrm{~A}(\mathrm{a})$

${ }^{4}$ See Carter v. Helmsley-Spear, Inc., 71 F.3d 77, 85 (2d Cir. 1995).

${ }^{5}$ Id.
}

who are genuinely interested in the problem topic work hard and display enthusiasm for the assignment. This hard work and enthusiasm, in turn, lead to thorough research, well-written briefs, and persuasive oral arguments.

Second, the people who are scoring the students' briefs and oral arguments - whether they are faculty, other students, or members of the local legal community - will be more engaged in the scoring process if the problem topic interests them. In other words, these judges will have more incentive to thoroughly prepare to score briefs and oral arguments if they are presented with an interesting problem topic. In my experience, this incentive results in detailed and constructive critiques of the students' briefs by the judges. It also produces active and relevant questioning by the judges during the students' oral arguments. And by receiving thorough, constructive criticism on their briefs and relevant, probing questions during oral argument, the students get more out of their appellate advocacy experience.

So what sorts of topics are interesting to students and judges? I have found that problems involving civil rights issues are typically the most interesting. In addition, problems that are based on issues "ripped from the headlines" also tend to be interesting. ${ }^{6}$ For example, over the last several years, the problem topics for our school's intramural moot court competition have included (1) whether a statute banning adoption by homosexuals is constitutional under the Due Process and Equal Protection Clauses of the Fourteenth Amendment; (2) whether a painted mural depicting the Ten Commandments, displayed in a county courthouse, is constitutional under the Establishment Clause of the First Amendment; and (3) whether the sentence for a federal conviction that includes a "shaming

\footnotetext{
${ }^{6}$ Of course, the problem topic should not be so new that there is little legal authority on the topic. If that is the case, the students working on the problem will struggle because they'll have few legal bases for the arguments that they make in their briefs and arguments.
}

66 So what sorts of topics are interesting to students and judges? I have found that problems involving civil rights issues are typically the most interesting. 9 


\section{The problem}

\section{should not contain}

overly complex

legal issues or

a confusing

procedural posture

that may be

difficult for the

students and

judges to

understand. "9 condition" violates the Federal Sentencing Reform Act. ${ }^{7}$ All of these problems were based upon issues that were a "hot topic" of discussion among the bench and the bar. The students who worked on these problems seemed to be genuinely interested in the problems. What is more, most of the students projected enthusiasm in their briefs and oral arguments. Finally, many of the briefs and oral arguments that I scored were engaging and thorough.

\section{Create a Manageable Problem}

A few years ago, our school's Moot Court Society hosted a regional round of a national moot court competition. A team of students from our school also represented the school in the competition. One issue from the competition problem was whether procedures provided in the United States Tax Court Rules were constitutional under the Due Process Clause of the Fifth Amendment. The problem also involved cross-appeals, under which each party was appealing a separate ruling by the lower court.

Unfortunately, the problem was confusing. Our school's team struggled to fully grasp the substance of the due process issue, as did a number of teams competing in the regional round that our Moot Court Society hosted. In addition, the judges were confused by the procedural posture of the case. Because the case involved cross-appeals, it was difficult for the judges to tell which party was the petitioner in the case and which was the respondent. Finally, the problem did not seem to be immediately engaging to either the advocates or the judges because of its dry and technical topic. As a result, some of the oral argument judges appeared to be ill-prepared. A few of them even admitted that they had spent little time reviewing the problem before judging oral arguments because of the confusing and technical nature of the problem.

Therefore, your second goal as an appellate problem writer should be to create a problem that the students can manage on a substantive and procedural level. The problem should not contain

\footnotetext{
718 U.S.C.A. $\$ \$ 3551-3626$
}

overly complex legal issues or a confusing procedural posture that may be difficult for the students and judges to understand. This goal is important for the students working on the assignment because the students will be relatively new to the process of persuasive writing and oral advocacy. Because of this, they will be absorbing and trying out skills that they haven't yet mastered. This newness to these persuasion skills causes anxiety in the students. In my experience, a needlessly complex problem only heightens their anxiety, which turns what should be a positive learning experience into a largely negative one.

As illustrated above by the national competition problem, the goal of creating a manageable problem is also important for the people scoring the briefs and the oral arguments. Complex problems may discourage some judges from familiarizing themselves with the problem material. This is particularly so if members of your local legal community will score the students' briefs and oral arguments. Many of these judges are busy practitioners who may have little time to prepare to judge. Providing a manageable problem topic makes their job easier. If the judges have an easier job of familiarizing themselves with the material, they will have more incentive to become familiar with the problem. And, when the judges are familiar with the problem, they are more able to contribute valuable feedback to the students tackling the problem.

A manageable appellate advocacy problem includes two components: (1) legal issues that a first-year law student will find challenging, but not overwhelming, and (2) an understandable procedural posture. As to the first component, you should feel reasonably comfortable with composing appellate advocacy problems that involve subjects your students have encountered in their first-year courses. For instance, problems involving tort law or criminal law issues typically work well. My school recently added constitutional law to the first-year curriculum. I was happy to see this change because I particularly enjoy assigning problems involving constitutional law issues. If constitutional law is part of your school's first-year curriculum, you might consider drafting a problem involving a constitutional law issue. While 
appellate advocacy assignments involving constitutional law have the potential to overwhelm students, I find that they work well as long as the issues presented in the assignment are narrow and well-defined. For example, the most recent problem for our school's moot court competition involved whether a public employee's firing was constitutional under the First Amendment's Free Speech Clause. Though the circumstances of the firing could also have given rise to a procedural due process issue, the students were instructed in the problem not to focus on the possible due process issue. This instruction kept the students focused on only the free speech issue, which gave them a greater sense of comfort with the problem.

As to the procedural posture of the problem, it should be one that the students have likely discussed in their first-year courses. The procedural posture certainly should not involve cross-appeals. One party should clearly be the appealing party and the other the responding party. I find that problems containing appeals from the grant of a pretrial motion (such as a motion for summary judgment or a motion to dismiss) or from a verdict after a full trial work well. These procedural postures usually present a standard of appellate review, such as de novo, that students have encountered in their first year of school. Consequently, the students will have little difficulty understanding the standard of review.

\section{Create a Realistic Problem}

The classic appellate moot court problem consists of only the order or opinion issued by the lower court, followed by the order from the appellate court certifying the issues to be briefed and argued on appeal. The lower court's order or opinion commonly contains a statement of the relevant facts from the case and an abbreviated analysis of the legal issues. On the basis of this abbreviated "record," the students must prepare to brief and argue the case.

Unfortunately, this sort of truncated appellate record creates an unrealistic environment for the students who are participating in the appellate advocacy exercise. For example, these records often leave out critical facts that would likely be present in the record of proceedings used in a real appeal. ${ }^{8}$ Additionally, the classic moot court record omits materials that a lawyer litigating a real appeal must deal with, such as the pleadings, motions, and transcripts of evidence from the lower court proceedings. Finally, these records occasionally contain concessions that parties in a real appeal would probably not make. ${ }^{9}$

As a result of the unrealistic environment created by the classic moot court problem, the students working on the problem are presented with several scenarios that real appellate lawyers normally don't encounter. First, the oral argument judges, especially those who are appellate practitioners, don't expect the record to omit important facts or to contain concessions that would not typically be made in a real appeal. Therefore, these judges often focus their questioning at oral argument on these omissions or concessions. Unfortunately, the students who are arguing the case are usually at a loss to explain these omissions or concessions, which often leads to the embarrassment of the students and to the judges going off on tangents in their questioning.

Second, unlike real appellate lawyers, who must sort through the record of proceedings to figure out which information is relevant to the appeal, the students are spoon-fed the relevant facts and law by the abbreviated record. Therefore, the students are prevented from practicing an essential lawyering skill—sifting through information to determine what's important to their client's case. Finally, the students simply don't get to see what a real appellate record looks like. Therefore, they may be presented with an unwelcome surprise-a voluminous record of proceedings - should they later take on a real appeal in practice.

\footnotetext{
${ }^{8}$ For instance, testimony of important witnesses may be omitted.

${ }^{9}$ Several years ago, the problem from a national moot court competition in which our school competed contained a curious concession. The appellant conceded that he could not prove an important component of a key defense that he had raised to the appellee's action, even when the evidence in the record of proceedings for the problem indicated the appellant could prove that component.
}

${ }^{66}$ As to the procedural posture of the problem, it should be one that the students have likely discussed in their first-year courses." 9 
66I am used to

hearing student

competitors

grumble about

'one-sided'

problems-

problems that

provide one side

to the case with

easier arguments

than the other

side."
Therefore, to avoid these issues with your students, your third goal as an appellate problem writer should be to provide the students with a record that approximates a real appellate record of proceedings. Write a record that contains the relevant pleadings, motions, and transcripts of evidence from the lower court. Make sure that the record doesn't omit critical facts or include odd concessions. To make your job easier, consult a record from a real appeal if you have access to such a record. This real-world record can serve as a template for the record that you will provide to your students and allow you to avoid "reinventing the wheel."

\section{Create a Well-Balanced Problem}

As the faculty adviser for a number of teams who have represented my school in interscholastic moot court competitions, I am used to hearing student competitors grumble about "one-sided" problems - problems that provide one side to the case with easier arguments than the other side. Sometimes, the students' complaints seem to be based on their misperceptions of the problem rather than the reality of the problem. But occasionally, I have seen appellate advocacy problems that are truly one-sided. ${ }^{10}$

In real appellate practice, the courts dispose of many cases that could be considered one-sided. Indeed, appellate courts across the country issue unpublished orders disposing of scores of routine appeals on a daily basis. But in many real appellate cases, both sides to the appeal have equally strong arguments. This is the sort of case that we, as teachers, should seek to replicate in the educational context. This is so because, in my experience, onesided appellate advocacy problems create two unwelcome issues for the students and the people who score their briefs and oral arguments. First, the

\footnotetext{
${ }^{10}$ Several years ago, a problem from a national moot court competition considered whether a criminal defense attorney who slept during his client's trial rendered ineffective assistance, thus violating the Sixth Amendment to the Constitution. According to the factual account in the problem, the defense attorney slept for at least half of the trial. The students representing the government had an extremely difficult time convincing the judges during the oral argument stage of the competition that the lawyer's conduct did not violate the Sixth Amendment's guarantee of effective counsel.
}

students may feel disadvantaged and, therefore, discouraged if they are assigned to argue the weaker side of the case. Consequently, these feelings may negatively impact their performance. Second, judges may give higher scores to students assigned to argue the stronger side of the case, even when the judges are specifically instructed not to let their personal views about the merits of the case impact their scoring.

Therefore, your last goal as an appellate problem writer should be to create a problem with strong arguments on both sides of the case. This will promote the students' confidence in the case, thus creating better performances, and will prevent judges from unfairly favoring certain advocates over others.

Unfortunately, achieving a well-balanced appellate advocacy assignment is probably the most difficult goal in problem writing. To create a balanced problem, I do two things that I have found to be extremely helpful. First, after gathering and reading the relevant authority for the problem, I create an argument "t-chart." On one side of the t-chart, I list the potential arguments for the appealing party in the case. On the other side, I list the potential arguments for the responding party. I then read through and consider all of these potential arguments. While the process is somewhat subjective, I ponder whether one side of the $\mathrm{t}$-chart outbalances the other side. If I find that there is a lack of balance, I consider ways in which I can alter the facts of the problem to achieve a better balance. I then implement those changes.

Second, I try to work with a problem-writing partner. At the very least, this partner should be available to simply review your work. At best, this person should co-author the problem with you. Either way, having another person involved in the process lends a fresh perspective to the process. Your partner, who is ideally a fellow faculty member but can even be a student who is a member of your school's moot court board or a practicing attorney, may see problems with the balance of the assignment that you may not see. And, if your partner is co-authoring the problem, there is the added benefit of dividing the labor with your partner. 
There is, however, a caveat here-there is no such thing as a perfectly balanced problem. Just as each side of any real case has strengths, it also has weaknesses. In fact, these weaknesses must be present in any appellate advocacy problem that you draft because in practice, your students will be forced to deal with the inevitable weaknesses of their clients' cases. Therefore, the students need weaknesses in any appellate advocacy assignment so they may hone their skills of minimizing the negative impact that those weaknesses have on the client's case. But, as emphasized above, your goal in drafting the assignment should be to ensure that the weaknesses on one side of the case are not so prevalent that students arguing that side of the case are unfairly saddled with a disadvantage.

\section{Generate Ideas for Problem Topics}

To achieve the foregoing goals, it's helpful to know which resources are useful to assist you in generating ideas for appellate problem topics. I consult a combination of print and online sources that contain regular discussions of current legal issues that are ripe for argument. As for print sources, I find that legal news periodicals are the best print sources to consult in generating ideas for problem topics. I typically consult legal news periodicals such as the National Law Journal, the ABA Journal, and the American Lawyer.

As for online sources, I visit a number of lawrelated Web sites that include a regular discussion of current legal topics:

- American Bar Association Preview of United States Supreme Court Cases $<$ www.abanet.org/publiced/preview /home.html $>$. This is a subscription-based Web site.

- American Civil Liberties Union <www.aclu.org>

- FindLaw ${ }^{\varpi}$ Legal News and Commentary $<$ news.findlaw.com $>$

- FindLaw U.S. Supreme Court Center $<$ supreme.lp.findlaw.com>

- Jurist Legal News and Research $<$ jurist.law.pitt.edu> n Law.com <www.law.com/index.shtml >

- Northwestern University Medill School of Journalism On the Docket U.S. Supreme Court News $<$ docket.medill.northwestern.edu $>$

- Oyez: U.S. Supreme Court Media $<$ www.oyez.org/oyez/frontpage $>$

Additionally, the Web blog craze has given rise to a number of excellent law blogs that routinely contain postings on current legal issues and litigation:

Appellate Law and Practice

<appellate.typepad.com/appellate>

- Balkinization <balkin.blogspot.com>

n How Appealing < howappealing.law.com>

n SCOTUSblog: Supreme Court of the United States Blog <www.scotusblog.com/movabletype >

n Split Circuits <splitcircuits.blogspot.com>

- The Volokh Conspiracy <volokh.com>

I try to check these sources on a weekly basis. If I find an article or blog posting that contains an interesting topic, I print out the piece and jot down the URL for the piece on the printed copy so I can access it online in the future. I then put the printed copy in a folder in my office marked "Potential Assignments." As the time comes for me to work on a new problem, I consult the printouts in my folder.

Teaching our students persuasive writing and oral advocacy skills is a critical task. As educators, our goal through this task must be to prepare our students to "hit the ground running" when they set foot in their new law offices after graduation. By presenting our students with appellate advocacy problems that are engaging, realistic, and balanced, we take an important step toward that goal.

(c) 2008 James D. Dimitri
${ }^{66}[T]$ here is no such thing as a perfectly balanced problem. Just as each side of any real case has strengths, it also has weaknesses."' 